joints densely short golden-yellow pilose. Wings hyaline, small crossvein at middle of discal cell, base of third submarginal cell at last fifth of distance between small cross-vein and apex of discal cell ; costa not enlarged. On the anterior part of the second abdominal segment are many rather large, transversely-elliptical punctures, and similar punctures also occur on some of the other segments. Antennæ similar in structure to those of pernicis.

$q$ same as the $f$, except that the pollen of the abdomen is darker, and the pile is shorter and sparser; ovipositor as long as the fifth, sixth and seventh abdominal segments taken together.

Length, 20 to $25 \mathrm{~mm}$. Los Angeles County, Cal. Six males and four females.

\title{
NOTES ON COLLECTING SOME OF THE SMALLER SESIIADE IN THE LONDON (ENGLAND) DISTRICT.
}

The one most commonly met with is S. tipuliformis, and is to be found sunning itself on the leaves of the currant bushes at the time when the fruit is about two-thirds grown, and on a bright sunny morning about ro o'clock, or afternoon about 4 o'clock, one can easily take from six to twelve in one or two hours. Once I found them assembling, and took some thirty or forty in a very short time. It is a little difficult to procure the larvæ, as they feed in the two-year-old wood, and, as this is the fruitproducing part, it is better not to cut it while the owner is about, and when you can cut, I have found so many blanks that the bushes have suffered more than the gain warranted.

The next species commonly met with is our red-banded one, S. myopaeformis, feeding in the bark of apple trees (about six feet from the ground), and can generally be found in gardens where Tipuliformis is found. I have never seen this moth at rest, and though one can generally count on taking several in a morning, one must watch the trunks of the trees and find them flying round and round, evidently for depositing eggs; cutting out the larvæ without doing much damage to the tree is hard, as they feed just under the bark.

Our next commonest one is S. culiciformis. For this we must go to the woods where birch is common; so, taking the train down to Croydon, ten miles (about the end of April), a two-mile walk brings us to West Wickham Wood, one of our best in the South London district. We go through it till we find a part which was cut down two winters back; 
here, having found some nice looking birch stumps with frass showing, we set to work with a saw to saw off the sides, and so find we have secured one or two larvæ or pupæ, and in a good afternoon's work may perhaps obtain twenty. These we take home and put on wet moss to prevent drying up, and with care may in about six weeks breed a good many. I have found putting them under a bell glass a good way. I have never taken this insect on the wing.

The next, $S$. formicaeformis, with its pretty claret-coloured wings, we flud flying in the sun along the sides of the roads which intersect our osier beds in the Mitcham district (about eight miles out). This species seems on the wing all the day, and ffteen or twenty is a fair catch. The larvæ can be cut out of the osiers about April, but it is very risky, as the basket makers have a decided objection to their osiers being cut.

$S$. chrysidifornis, the handsomest of all our smaller Sesiiadæ, with its bright scarlet wings, was, until some twelve years ago, most rare, fetching as much as two and three pounds per pair, but about that time they found out how to take the larvæ. Starting from the London Bridge station, on the S. E. R., we take tickets for Folkestone (town station). Arriving there after about two and a-half hours' rin, we turn towards the Warren (a sort of undercliff running along the shore for about three miles), and after a mile's walk we get on to the slopes closest to the sea. Having brought a good, sharp, two-inch chisel with us, we look round for roots of dock and sorrel; the former we find are very scarce, having been cleared off by collectors; the latter, however, are still common, and having selected a good strong one dig it up, and scraping part of the root away see signs of workings. We put the root into a small sack we have provided and then search for more. In the course of a day we get a nice lot together, and upon our arrival home plant them into boxes. As it is only April, and the imago will not be out till June, there is now nothing else to do but to keep them watered and cover over with muslin till about the end of May. One year, from three days' work in Folkestone Warren, I bred about 50 fine imagos.

S. cynipiformis, feeding in oak, is said to occur in Hyde Park, but I have never been able to find it there. However, I have obtained the larve commonly at Tilgate in early May by finding the trunks of large oaks which have been cut down two winters previous, then ripping off the bark the larve are found feeding in it. In Fingland the trees are cut off only four or five inches fron the ground, and the moths seem to prefer 
these to the growing tree. There, however, appears plenty of sap to support the larvæ till full grown. The only trouble, having got the larvæ, is to prevent drying up till time of emergence.

S. ichneumoniformis. I have never bred and have only taken it very sparingly by sweeping the herbage along the edge of cliff at Eastbourne and Ramsgate. The most I ever took in a day was five.

S. sphegiformis (one of our rarest ones, which is taken every year), has to be cut out of the alder. About March we take train for ThreeBridges Station, thirty miles out on the Brighton line. Arriving there we are soon on the ground and examining the alder stems from one to four inches thick. When we find workings which would denote larve in the second year, we saw off just below and then again about eighteen inches higher, and if very lucky we may get from ten to thirty sticks in a day. These have to be kept on moist moss in tin boxes till the middle of June, when the moth appears. Having a nice $q$ quite fresh, we are off by the first train, and having put her in a collar box with muslin on each side, we nang it to a bough and sit down and wait events. Perhays nothing for the first half hour, but what is that buzzing in front of the box? We get up quic'ly and see it is a fine $\delta$. We need no net; he is so intent that we hold our bottle just behind him and bottle him on the wing. By this means I took twenty-three in one day. The curious part is, I never saw them coming until they were quite at the box hovering, and also that an insect so quick on the wing should not fly off, even when the bottle is as it were all round it and only the cork to put on.

$S$. scoliaeformis was taken out of birch fairly commonly at Llangollen, Wales, some twenty years back, but was quite worked out then, and for some fifteen years no one had taken it. However, last year in Scotland I hear it has been taken fairly commonly.

S. philantiformis was added to our list only some ten years back. It was found by accident feeding in the common thrift on the sea coast in the west of England, but I have never taken it.

$S$. vespiformis and $S$ andreniformis, the two remaining of our smaller Sesiiadæ, are of the greatest rarity, and have only been taken singly.

Regarding Tipuliformis, in 1874 and 1875 I took and saw several in Mr. B. Gibb's garden, St. Catharine street, Montreal, among the currant bushes, and I should think it would be found in any of our old town gardens now.

Lachlan Gibb. 